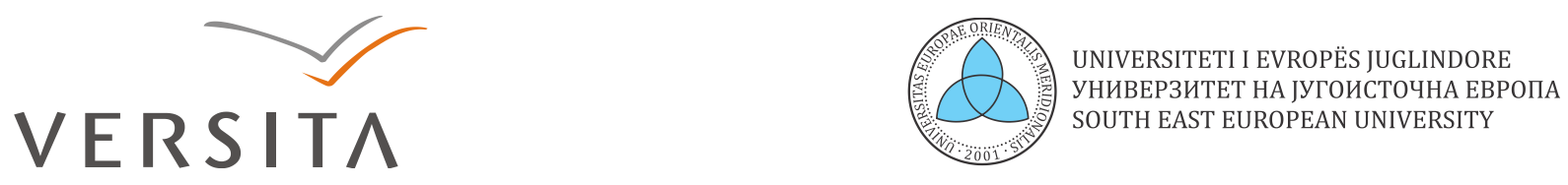

\title{
COAL COMBUSTION BYPRODUCTS AND THEIR USAGE - WATER FIELD
}

\author{
Figene Ahmedi, PhD \\ Civil Engineering and Architecture Faculty \\ Email: figene.ahmedi@uni-pr.edu \\ Laura Kusari, PhD \\ University of Prishtina \\ Email: laura.kusari@uni-pr.edu \\ DOI: 10.2478/v10306-012-0014-5
}

\begin{abstract}
One of the environmental challenges is a management of solid wastes produced by industrial activities. Among these industrial activities is energy production from power plant, which produces the waste material during the coal combustion processes. The power plant during the coal combustion processes produces the fly ash, bottom ash and boiler slag. These are solid wastes commonly referred to as coal combustion byproducts (CCBs). The coal combustion byproducts are managed in two ways: They may be disposed of in landfills or surface impoundment ponds, or they may be used in some capacity (commonly referred to as "beneficial use"). In this paper an overview of coal combustion byproducts and their physical properties are presented. The benefits of utilizing CCBs in certain application implying the utilization of CCBs in water and wastewater treatment domain are provided here as well. In fact, this paper attempts to encourage and promote the utilization of native coal combustion byproducts where the needs arise. The appropriate studies of native CCBs provide an opportunity to use these materials for supplemental needs in water environment in the future.
\end{abstract}

Keywords: Waste material, coal combustion byproducts, fly ash, bottom ash, boiler slag. 


\begin{abstract}
Abstrakt
Një ndër sfidat mjedisore është menaxhimi i ndotjeve të ngurta të cilat gjenerohen nga aktivitetet industriale. Midis aktiviteteve industriale është edhe prodhimi i energjisë nga uzinat energjetike të cilat prodhojnë material ndotës gjatë proceseve të djegies së thëngjillit. Uzina e energjisë gjatë djegies së thëngjillit prodhon hirin fluturues (fly ash), hirin fundor (bottom ash) dhe zgjyrën (boiler slag). Këto janë ndotje të ngurta të cilat quhen nënprodhime të djegies së thëngjillit (CCBs). Nënprodhimet e djegies së thëngjillit menaxhohen në dy mënyra: mund të hidhen në deponi apo sipërfaqe të mbyllur, apo mund të shfrytëzohen për përdorim të caktuar (shpesh të referuar si "shfrytëzim përfitues"). Në këtë punim ofrohet një përmbledhje e nënprodhimeve të djegies së thëngjillit dhe prezantohen vetitë e tyre fizike. Përfitimi i shfrytëzimit të këtyre nënprodhimeve në aplikime të caktuara përfshirë shfrytëzimin e tyre edhe në domenin e trajtimit të ujërave dhe ujërave të ndotura po ashtu ofrohet në këtë punim. Në fakt, punimi përpiqet t'i inkurajojë dhe t'i nxisë përdorimin e nënprodhimeve të djegies së thëngjillit vendor aty ku është e mundshme. Studimet e mirëfillta të nënprodhimeve të djegies së thëngjillit ofrojnë mundësi për shfrytëzim të këtyre materialeve për nevoja të mundshme në fushën e ujërave në të ardhmen.
\end{abstract}

\title{
Апстракт
}

Еден од еколошките предизвици е менаџирањето на цврстиот отпад создаден при индустриски активности. Една од овие индустриски активности е прозводството на енергија од електрични централи кои создаваат отпаден материјал во процесот на согорување на јаглен. Во процесот на согорување на јагленот, електичната централа создава летечки пепел (fly ash) долен пепел (bottom ash) и згура (boiler slag). Овие материи се сметаат за цврст отпад кој најчесто се нарекува нуспроизводи од согорување на јаглен $(C C B s)$. Нуспроизводите добиени при согорување на јаглен се менаџираат на два начина: тие можат да се одлагаат на депонии или базени за површинско каптирање (surface impoundment ponds) или, пак, може да им се најде некоја друга употребна вредност (најчесто наречено „корисна примена”). Во овој труд се дава преглед на нуспроизводите добиени при согорување на јаглен и се презентираат нивните физички карактеристики. Истовремено се разгледуваат и придобивките од искористувањето на CCBs во одредени постапки со посебен осврт на корисноста на CCBs во третманот на води и отпадни води. Всушност овој труд има за цел да го потттикне и да го промовира искористувањето на нуспроизводите од согорување на природен јаглен онаму каде што за тоа се јавува потреба. Студиите за нуспроизводите од согорување природен јаглен нудат можност за искористување на овие матријали за дополнителни потреби во водената животна средина во иднина. 


\section{Introduction}

Widespread industrial activities as well as power plant for energy production are producing large amount of solid waste materials. Some of these materials are being put to use while others find no proper utilization and are dumped elsewhere. The industrial waste material is available almost at no cost and may be used as low cost material providing a twofold advantage: Firstly, the volume of waste materials would be partially reduced and secondly, the low cost material would fulfill the supplementary needs in certain domains. The use of coal combustion byproducts as solid waste materials produced after the combustion of coal to produce electric power, has become an area of intense interest, research, and activity, during the last decade. Therefore, next, in this paper we discuss about the coal combustion byproducts, their physical properties, and for the benefits on utilizing the $\mathrm{CCBs}$ in certain domains. This may in future guide investigations towards using native CCBs as useful materials in order to resolve the waste material into a useful one. Another reason which attract researchers in finding the solution of using the native CCBs is that they are accessible and almost with no cost.

\section{Coal for Energy Production}

Coal is a material who's primary component is the carbonaceous material. The latter, is accumulated as a plant matter in marine or freshwater environments and marshes. The accumulation of plant matters consolidate into the coal through a process called coalification, a process which takes millions of years. Depending on the age of coal and the amount of the carbon it contains, the coal may be classified into four types: lignite, bituminous, subbituminous and anthracite. Lignite is the youngest coal, with the lowest carbon content $(25 \%-35 \%)$, thus the lowest heating value (energy content) as well. Subbituminous and bituminous coals are of intermediate age and have slightly more energy content due to a slightly more amount of carbon content on them (subbituminous $35 \%-45 \%$ and bituminous $45 \%-86 \%$ ) than lignite coal. Anthracite coal contains typically more carbon (more than 90 $\%$ ), and has energy slightly higher than bituminous. Different types of coal are used in different countries, but its utilization is the same worldwide the world - it is used as a major source of energy production. In order to efficiently generate energy, pulverized coal is generally burned. Burning of coal is realized throughout processes in the combustion coal system. The coal combustion process may be different for different places, but the waste generated by the most of coal combustion facilities is the same. In fact, during the combustion process of pulverized coal in coal technology combustors, the ash is collected/produced. The ash collected from pulverized-coal-fired furnaces is fly ash, bottom ash and boiler slag. In general, coal combustion mostly results in fly ash, and the remainder is coarser bottom ash or boiler slag. The term coal combustion byproducts (CCBs) refers to fly ash, bottom ash and bottom slag. The distinction between fly ash and bottom ash is on how they form and exit from boiler. Fly ash exits in the flue gas (line with gas and fly ash), where it is subsequently collected with electrostatic precipitator or by a variety of other devices (by air pollution control equipment, such as electrostatic precipitator, baghouses, or wet scrubbers), whereas bottom ash exits from the bottom of the boiler. Coal combustion byproducts differ also on their physical characteristics (Tishmack \& Burns, 2004). 


\subsection{Coal combustion byproducts}

\section{Fly Ash}

Fly ash is a heterogeneous mixture of inorganic particles, which vary in shape, size and composition. Fly ash is finer than other byproducts consisting mostly of silt-sized and claysized glassy sphere particles, which can be less than $1 \mu \mathrm{m}$ to more than $1 \mathrm{~mm}$ in size. This gives fly ash a consistency somewhat like talcum powder. Table 2.1 lists physical properties of fly ash (Naik \& Chun, 2003; EERC).

Table 2. 1. Physical properties of fly ash

\begin{tabular}{cc}
\hline Property & Fly Ash \\
\hline Specific gravity & $1.59-3.1$ \\
Dry bulk density & $1.0-1.6 \mathrm{~g} / \mathrm{cm}^{3}$ \\
Surface area & $0.2-3.06 \mathrm{~m}^{2} / \mathrm{g}$ \\
Saturated hydraulic conductivity & $10^{-6}-10^{-4} \mathrm{~cm} / \mathrm{s}$ \\
\hline
\end{tabular}

Adapted by: (Tishmack \& Burns, 2004)

Fly ash has pozzolanic (containing glassy silica and alumina) or cementing properties. Materials with the pozzolanic properties have some self-cementing properties, respectively, the ability to harden in the presence of the water.

The pozzolanic and cementing properties of fly ashes are different for various types of coal. Considering that there are four types of coal: anthracite, bituminous, subbituminous and lignite, the pozzolanic and cementing properties are different for each of them. Fly ash that is produced by burning the anthracite or bituminous coal is typically pozzolanic. Fly ash that is produced by burning the lignite or subbituminous has cementing properties. Depending on the coal type burned, and the carbon content in coal, the color of fly ash also varies. The color of the bituminous fly ash is usually some shade of gray, with the lighter shades of gray generally indicating a higher quality of ash. Fly ash generated from lignite combustion is generally light tan to buff in color, indicating relatively low amount of carbon, as well as the presence of some lime or calcium (Recycled Materials Resource Center). Anthracite coal burns quite little in utility boilers, hence there are only small amounts of anthracite coal fly ash generally available. The carbon content and other chemical components of fly ash vary with coal rank. The major constituents of the coal fly ash residues are presented in the Table 2.2 .

Table 2. 2. Normal range of the chemical composition of fly ash produced from different coal type

\begin{tabular}{cccc}
\hline Component & Bituminous (\%) & Subbituminous (\%) & Lignite (\%) \\
\hline $\mathrm{SiO}_{2}$ & $20-60$ & $40-60$ & $15-45$ \\
$\mathrm{Al}_{2} \mathrm{O}_{3}$ & $5-35$ & $20-30$ & $10-25$ \\
$\mathrm{Fe}_{2} \mathrm{O}_{3}$ & $10-40$ & $4-10$ & $4-15$ \\
$\mathrm{CaO}$ & $1-12$ & $5-30$ & $15-40$ \\
\hline
\end{tabular}




\begin{tabular}{cccc}
\hline $\mathrm{MgO}_{\mathrm{SO}_{3}}$ & $0-5$ & $1-6$ & $3-10$ \\
$\mathrm{Na}_{2} \mathrm{O}$ & $0-4$ & $0-2$ & $0-10$ \\
$\mathrm{~K}_{2} \mathrm{O}$ & $0-4$ & $0-2$ & $0-6$ \\
$\mathrm{LOI}$ & $0-3$ & $0-4$ & $0-4$ \\
\hline
\end{tabular}

Adapted by: (Recycled Materials Resource Center)

Table 2.2 shows that lignite and subbituminous coal fly ashes are characterized by higher concentration of calcium and magnesium oxide, and reduced percentages of silica and iron oxide, when compared to bituminous coal fly ash. It also shows that silica, alumina and iron oxide are in higher content in bituminous coal fly ash than in lignite and subbituminous coal fly ashes. LOI is expressed as loss on ignition and refers to the amount of unburned carbon which remains in fly ash. Given the value of the LOI in fly ash, one may determine the amount of carbon in coal fly ash. According to this, lignite and subbituminous coal fly ashes have less carbon than bituminous coal fly ash. This may have also been inferred given the light or gray color of fly ash.

\section{Bottom Ash}

Bottom ash is a coal by product with grain size ranging from fine sand to fine gravel and is coarser than fly ash. Bottom ash particles are generally non-spherical and are typically composed of particles ranging from $2 \mu \mathrm{m}$ to $25 \mathrm{~mm}$ in size. Bottom ash particles could be rounded in shape, but are generally angular (Naik \& Chun, 2003). Bottom ash is incombustible byproduct that is collected from the bottom of furnaces that burn coal (from pulverized-coal fire furnance). The color of bottom ash is a glassy, dark gray material (EERC). Some of the physical properties of bottom ash are given in Table 2.3.

\section{Boiler Slag}

Boiler slag is formed in cyclone boilers, and is produced as a molten ash cooled with water. The boiler slag particles are generally non-spherical ranging in size from coarse sand to fine gravel, and have a smooth appearance. The boiler slag particles are typically composed of particles ranging from $2 \mu \mathrm{m}$ to $15 \mathrm{~mm}$ in size. Boiler slag is generally a glassy, black granular material with numerous engineering applications (Naik \& Chun, 2003; EERC). 
Table 2. 3. The physical properties of bottom ash and boiler slag

\begin{tabular}{ccc}
\hline Property & Bottom Ash & Boiler Slag** \\
\hline Specific Gravity & $2.17-2.78$ & $2.3-2.9$ \\
Dry bulk density & $0.74-1.6 \mathrm{~g} / \mathrm{cm}^{3}$ & $0.96-1.44 \mathrm{~g} / \mathrm{cm}^{3}$ \\
Surface area & $0.4 \mathrm{~m}^{2} / \mathrm{g}$ & - \\
Saturated hydraulic conductivity & $10^{-3}-10^{-1} \mathrm{~cm} / \mathrm{s}$ & - \\
\hline
\end{tabular}

Adapted by: * - (Tishmack \& Burns, 2004); ** - (Naik \& Chun, 2003)

The major chemical components of bottom ash are the same as of fly ash. Bottom ash and boiler slag are composed particularly of silica, alumina and iron oxide, with smaller percentages of calcium and magnesium oxides, sulfates and other compounds. Bottom ash and boiler slag derived from lignite or subbituminous coals has a higher percentage of calcium oxide than bottom ash or boiler slag from anthracite or bituminous coals (Recycled Materials Resource Center).

\subsection{Environmental issues of coal combustion byproducts}

The ash, as it is produced by power plant, is disposed of in landfills. The problem with CCBs lies in fact that not only does its disposal require large quantities of land, its fine particles, if not managed well will cause air, water, and soil pollution, a disruption of ecological cycles, and setting off environmental hazards. Coal combustion byproducts contain those same elements that make up the natural soil. In fact, approximately $99 \%$ of CCBs is made up of $\mathrm{Si}, \mathrm{Al}, \mathrm{Fe}, \mathrm{Ca}, \mathrm{K}, \mathrm{Mg}, \mathrm{Na}, \mathrm{O}$ and $\mathrm{P}$. The remaining percentage is of trace elements that are of a great environmental concern. The route of the trace elements exposure may be through leachate that enters groundwater, or through runoff that enters surface waters which may then be used by plants, animals or humans (Tishmack \& Burns, 2004; Debra \& David, 2001). (Recycled Materials Resource Center) suggest that: "in particular, areas with sandy soils possessing high hydraulic conductivities and areas near shallow groundwater or drinking aquifers should be given careful consideration". According to (Tishmack \& Burns, 2004), leachability of trace elements from CCBs is a function of their type and hydration behavior. The leachability of metals from lignite and subbituminous CCBs is lower than from bituminous CCBs due to the creation of hydrated minerals. If not properly disposed of, CCBs solids will pollute not only water, but also the air, causing respiratory problems when inhaled or ingested directly by animals and humans (Tishmack \& Burns, 2004).

Another issue of concern, in relation to the disposal of CCBs is that disposal sites have limited capacity. Construction of new disposal sites may require considerable costs, such as land purchase, population displacement, land preparation, as well as excavation, transport, and placement of generated ash (Groppo, Robl, \& Hower, 2004). A reduction of ash disposal sites, as well as of the amount of the ash itself within storage may be reached when 
considering some beneficial use of CCBs. If a considerable amount of processed ash may be turned into a useful product, the need for additional storages is automatically reduced (Groppo, Robl, \& Hower, 2004).

Reduction of ash disposal sites by utilizing ash in certain domains may be accomplished if the exposure risk of CCBs solids and leachate is well managed. Assuring a reasonable level of the environmental safety, solid conditions for CCBs marketing may further be provided (Debra \& David, 2001).

\section{Benefits of Utilizing Coal Combustion Byproducts}

Back to the history of coal ash utilization as mineral filler in asphalt mixes in year 1930, the potential of coal ash for certain application areas is becoming more and more acceptable. EPA in 1993 issued its final regulatory determination, and continued to exempt coal ash from regulation as hazardous waste.

According to (Naik \& Chun, 2003), from about 560 million tons (Mt) of fly ash, bottom ash and boiler slag produced in the world in 1989, only 90 Mt out of it (16\% of the total) was utilized. The utilized ash has been useful: for road subbase construction (placed directly on top of the undisturbed soil so as to support the top layer of the pavement); as aggregate substitute material (e.g., for brick production); for concrete production as substitute material for portland cement (the portland cement is replaced with fly ash); for embankments and other structural fills - usually for road construction avoiding creation of low areas (by excavation of soil to be used for construction of embankments); for agricultural uses as soil modifier improving the plant's water and nutrient uptake; as loose application on rivers to melt ice; as loose application on roads and parking lots for ice control.

To summarize, the utilization of coal combustion byproducts results in numerous benefits, including:

- Reduction of the demand of land for disposal/deposition of ash that otherwise would not have been used for a given application. A decrease in the demand for landfill space.

- Conservation of natural resources.

- A cleaner and safer environment.

- Reduced carbon dioxide emissions.

- Significant economic savings for end users.

- A boost in economic development.

- Reduced overall cost of generating electricity.

These benefits are affected by the fineness, loss on ignition and chemical content of the coal ash. In fact, the properties of CCBs are such that, in many applications, they improve the product. In engineering construction materials, coal ash could add value and enhance strength 
and durability while reducing costs. In agricultural applications, gypsum-rich products can provide plant nutrients (EERC).

Based on available data for production and use of ashes worldwide, (Naik \& Chun, 2003) gave also the data for Former Yugoslavia. According to them, in Former Yugoslavia in 1989, there were 13337 tons of ashes produced, and only 862 tons out of them were utilized (Naik \& Chun, 2003). In 2006, around 125 million tons of coal combustion byproducts were produced in the U.S. each year, with about $43 \%$ of the amount used in commercial applications, according to the American Coal Ash Association web site. As of early 2008, the US EPA hoped that figure would increase to $50 \%$ since 2011.

The utilization of coal ash across EU countries is different and is mainly based on national experience and tradition. The utilization of coal combustion byproducts in many application areas substituting natural materials have to fulfill technical and environmental requirements as required by the standards and regulations (Feuerborn, 2005). One of the main attractions of using coal ash is that it is generally free, or at a low cost wherever it is produced, so the economics appear to be attractive. Another advantage of using the coal residual is that, since coal residuals may be used for the treatment of wastewater, the wastewater residuals - sludge appear suitable in highway construction and structural fills (Viraraghan).

\section{Coal combustion byproducts for the water field}

Another area, where possible utilization of coal combustion byproducts (CCBs) is appeared, is water and wastewater treatment. The utilization of CCBs in water and wastewater treatment is shown by many researchers and practitioners, whose most challenging task is clean water for various activities (Bhatnagar \& Minocha, 2006). The researchers have investigated the performance of coal residuals as material component of certain treatment systems for water and wastewater treatment. (Viraraghan) in his work reviews papers on ash utilization in water management. According to him, Balance et al., (1966) show that using fly ash as aid of coagulant in water treatment helps in coagulation of turbid water, and also in settling of chemically induced flock.

Use of coal combustion byproducts is effective in wastewater treatment also. Bottom ash and fly ash are considered to be an alternative for wastewater treatment thorough on-site systems. Using bottom ash as a material content of a filter medium, for mound type soil absorption systems in laboratory work, a reduction of biochemical oxygen demand (BOD) and suspended solids (SS) is accomplished. The work is carried out at West Virginia University. A comparative study with pea gravel, medium sand, bottom ash and fly ashbottom ash mixture is performed in request of chemical oxygen demand (COD) and total suspended solids (TSS) reduction. Unscreened bottom ash used in a single intermittent filter for septic tank effluent treatment at Southern Illinois Power Co-op showed the average effluent values for BOD and SS to be 7 and $8 \mathrm{mg} / \mathrm{l}$.

The investigations by Eye and Basu (1970), related to municipal wastewater treatment using fly ash showed that, the reduction capability of COD of secondary effluent was by about $30 \%$ when initial COD is around $60 \mathrm{mg} / \mathrm{l}$, and removal of SS by coagulation with lime was very efficient (Viraraghan). 
Fly ash utilization for municipal wastewater treatment has shown to be successful taking it as an adsorbent (chemical process) for removal of color. The mixture of fly ash and coal in ratio 1:1 for the removal of chrome dye (in a commercial textile dye) substitutes activated carbon as a material for color removal. The achieved removal of dye was $100 \%$ at $10 \mathrm{mg} / \mathrm{l}$ respectively. Fly ash has a significant capacity for adsorption of organic pollutants by adsorbing the contaminants onto fly ash. It was reported that the residual carbon content of fly ash plays a significant role during the adsorption of organic compounds by fly ash (Viraraghan).

(Sahu, Dahiya, \& Gadgil), investigate the use of bituminous fly ash as an adsorbent for the treatment of domestic wastewater. Considering that activated carbon has high cost and about $10-15 \%$ loss during regeneration the use of fly ash (and other unconventional adsorbents like peat, lignite, baggase pith, wood, saw dust etc.) has attracted the attention of several investigations for the removal of constituents in wastewater. In fact, authors demonstrate the use of fly ash as an alternative media over activated carbon for COD removal. The results of the batch experiments show that COD present in domestic wastewater can be reduced up to the extent of $87.89 \%$ by the use of fly ash.

\subsection{Bottom ash of Kosovo's power plant}

The power plant "Kosovo A" in Kosovo operates for energy production using lignite as a coal material for combustion. During the combustion process, the lignite byproducts are discharged. Those coal combustion byproducts are all land-filling, which means that they have been not recycled nor used for supplemental needs like road construction, or water and wastewater treatment. The disposal material used in the experiment conducted by (Ahmedi \& Pelivanoski, 2012), was the bottom ash taken from the power plant "Kosovo A" - few kilometers outside Prishtina. Recently, the native bottom ash is analyzed of its physical operation in order to operate as media filter for the treatment of wastewater. The physical parameters of bottom ash in its natural state are analyzed initially. The values of effective size and uniformity coefficient as well as the porosity are estimated if they reach the recommended values from literature of physical characteristics. Findings show that native bottom ash may operate hydraulically even when derived (from natural state) within recommended values of physical characteristics and hydraulic properties.

\section{Conclusion}

In this paper, an overview of coal combustion byproducts, their physical characteristics as well as the benefits when utilizing CCBs in certain domains is introduced. The trends in research towards utilization of $\mathrm{CCBs}$ in water and wastewater treatment field are introduced here as well. These are findings which argue that coal combustion byproducts attract attention for the utilization in the field of water. In the end, the findings regarding to the hydraulic operation of bottom ash taken from Kosovo's power plant are provided.

The main contribution to this paper is to encourage the researchers in findings the application of native coal combustion byproducts. Whenever there is a shortage of natural resources, industrial byproducts yet attract attention as potential materials for certain domains. A prerequisite to the utilization of coal combustion byproducts in certain 
application is to resolve a native disposal material into a beneficial material. The recycling of coal combustion byproducts into useful products may be considered for the use in the field of water and wastewater treatment as well. The opportunity of returning the CCBs into a useful product will affect automatically the reduction of the CCBs disposal sites. This is a possible issues referring to the fact that CCBs are easely to reach and at low cost. In fact, this paper paves the path for investigating coal combustion byproducts for their potential in water environment. 


\section{References}

1. Ahmedi, F., \& Pelivanoski, P. (2012). Botom ash behavior as a filter material of bed filters on small scale on-site wastewater treatment systems. BALWOIS - 5th International Conference on Water, Climate and Environment. Skopje, Macedonia.

2. Bhatnagar, A., \& Minocha, A. K. (2006). Conventional and Non-Conventional Adsorbent for Removal of Pollutants from Water. Indian Journal of Chemical Technology, 13, 203-217.

3. Debra, H. P., \& David, H. (2001). Developing Beneficial Use Rules for Coal Combustion Products (CCPs). International Ash Utilization Symposium. Lexington: Center for Applied Energy Research and University of Kentucky.

4. EERC. (n.d.). University of North Dakota. Retrieved December 12, 2010, from Coal Ash Research: http://www.undeerc.org/carrc/

5. Feuerborn, H. J. (2005). Regulations Regarding Coal Ash Utilisation in Europe. Workshop on Environmental and Health Aspects of Coal Ash Utilization. Tel-Aviv, Israel: NCAB.

6. Groppo, J., Robl, T., \& Hower, J. C. (2004). The Benificiation of Coal Combustion Ash. In S. P. Giere R., R. Giere, \& P. Stille (Eds.), Energy, Waste and the Environment: A Geochemical Perspective (pp. 247 - 263). London: The Geological Society of London.

7. Naik, T. R., \& Chun, Y. (2003). International Coal Combustion Products Generation and Use. Warsaw, Poland: Center for By-Products Utilization.

8. Recycled Materials Resource Center. (n.d.). Retrieved December 12, 2010, from User Guidelines for Byproducts and Secondary Use Materials in Pavement Construction: http://www.rmrc.unh.edu/start.asp

9. Sahu, R., Dahiya, R. P., \& Gadgil, K. (n.d.). Fly Ash Based Low Cost Method for COD Removal from Domestic Wastewater. New Delhi: Center for Energy Studies Indian Institute of Technology.

10. Tishmack, J. K., \& Burns, P. E. (2004). The Chemistry and Mineralogy of Coal and Coal Combustion Products. In G. R, S. P., R. Giere, \& P. Stille (Eds.), Energy, Waste and the Environment: A Geochemical Perspective (pp. 223 - 246). London: The Geological Society of London.

11. Viraraghan, T. (n.d.). Ash Utilization in Water Quality Management. Canada: Faculty of Engineering, University of Regina. 